\title{
Keefektifan Program Adventure Based Counseling untuk Meningkatkan Kebahagiaan Mahasiswa
}

\author{
Aprilia Setyowati*, Siti Partini Suardiman, Mufied Fauziah \\ Program Studi Bimbingan dan Konseling, Fakultas Keguruan dan Ilmu Pendidikan, \\ Universitas Ahmad Dahlan, Jl. Pramuka No. 42, Yogyakarta, Daerah Istimewa Yogyakarta, Indonesia 55161 \\ *Penulis koresponden, e-mail: aprilia.setyowati@bk.uad.ac.id
}

Artikel diterima: 29 November 2018; direvisi: 21 Mei 2019; disetujui: 23 Mei 2019

\begin{abstract}
A happy individual tends to produce positive things in life in terms of social self; study; and career aspects. This research is to find out the effectiveness of adventure based counseling (ABC) program to improve happiness in students. This research was conducted using experimental design with one group pretest-posttest model. The subject of this research was eleven students in the third semester of study program of guidance and counseling, Universitas Ahmad Dahlan (UAD) who were selected using purposive sampling technique. The pretest and posttest data was collected using a scale which was developed based on Seligman theory. The data was analyzed by non-parametric data analysis of Wilcoxon test. The results show that $\mathrm{ABC}$ program does not significantly influence happiness in students, but it gives influence to the aspect of meaningfulness and achievement.
\end{abstract}

Keywords: adventure based counseling; increase happiness; increase meaningfulness; increase achievement

\begin{abstract}
Abstrak: Individu yang bahagia cenderung menghasilkan hal-hal yang positif dalam aspek pribadisosial; belajar; dan kariernya. Penelitian ini bertujuan mengetahui keefektifan program $A B C$ untuk meningkatkan kebahagiaan mahasiswa. Penelitian dilakukan menggunakan experimental design dengan model one group pretest-posttest. Subjek penelitian adalah sebelas mahasiswa semester tiga program studi bimbingan dan konseling UAD yang dipilih dengan teknik purposive sampling. Pengumpulan data pretest dan posttest dilakukan menggunakan skala yang dikembangkan berdasarkan teori Seligman. Data dianalisis menggunakan teknik analisis data non-parametrik dengan Uji Wilcoxon. Hasil menunjukkan pemberian program $A B C$ tidak berpengaruh signifikan terhadap kebahagiaan mahasiswa, namun berpengaruh terhadap aspek kebermaknaan dan prestasi.
\end{abstract}

Kata kunci: adventure based counseling; meningkatkan kebahagiaan; meningkatkan kebermaknaan; meningkatkan prestasi

\section{PENDAHULUAN}

Kebahagiaan merupakan suatu perasaan di dalam diri seseorang yang berupa emosi positif; keadaan yang positif; kegiatan positif dan komponen penting yang turut menentukan kualitas hidup individu (Hapsari, 2015). Jika seorang individu merasakan ketidakbahagiaan, hal tersebut dapat menyebabkan perilaku menyimpang. Survei Komisi Nasional Perlindungan Anak (KOMNAS-PA) yang dikumpulkan dari 4.726 responden siswa Sekolah Menengah Pertama (SMP) dan Sekolah Menengah Atas (SMA) di tujuh belas kota besar menunjukkan 97\% siswa SMP mengaku pernah menonton film porno, dan 93,7\% mengaku pernah melakukan berbagai macam adegan intim dengan lawan jenis, sesama pelajar. Lebih lanjut, setengah dari jumlah gadis muda perkotaan dan 62,7\% pelajar putri SMP mengaku tidak perawan. Hasil survei KOMNAS-PA di waktu yang tak berbeda jauh, menunjukkan 21,2\% siswi SMP mengaku pernah melakukan aborsi ilegal. Dari survei yang diselenggarakan KOMNAS-PA tersebut, 
terungkap bahwa tren perilaku seks bebas pada remaja Indonesia tersebar secara merata di seluruh kota dan desa, dan terjadi pada berbagai golongan status ekonomi dan sosial, baik kaya maupun miskin (Siahaan, 2014).

Pendidikan bertujuan untuk menghasilkan seorang manusia yang baik, dan untuk menjadi manusia baik, manusia harus belajar mengendalikan aktivitas hewaninya dengan cara menggunakan akalnya (Moseley, 2010). Ketika manusia berperilaku dengan sifatnya sebagai makhluk rasional, manusia akan mampu mencapai kebahagiaan. Pendidikan harus bertujuan pada keseluruhan perkembangan potensi setiap manusia. Pencapaian-pencapaian tujuan inilah yang berujung pada kebahagiaan yang disebut Aristoteles sebagai kebaikan tertinggi yang paling diinginkan setiap manusia. Pada proses pencapaian tujuan, pendidikan berfungsi meningkatkan kualitas manusia. Secara luas, tujuan pendidikan terarah pada hal-hal yang ingin dicapai selama hidup atau sama dengan tujuan hidup. Tidak ada individu yang ingin memperoleh tujuan hidup negatif, yang ada ialah tujuan hidup yang sempurna secara material, spiritual, serta menyangkut seluruh aspek kepribadian manusia (Somarya \& Nuryani, 2011).

Penelitian menggunakan $A B C$ telah banyak dilakukan, seperti untuk meningkatkan resiliensi (Whittington dkk., 2016); untuk pengoperasian perilaku adaptif (Christian dkk., 2017); serta meningkatkan kecerdasan adversitas (Kusherdyana dkk., 2016). $A B C$ juga terbukti banyak membantu konseli (DeDiego dkk., 2017; Fletcher \& Hinkle, 2002; Tucker, 2009; Tucker dkk., 2013), juga dapat digunakan untuk meningkatkan kebahagiaan (Albright, 2016; Nugraha, 2018). Selain kebahagiaan, $A B C$ juga dapat meningkatkan konsep diri (Fleischer dkk., 2017); self-efficacy; kepercayaan diri; dan wellbeing. $A B C$ bahkan dapat digunakan untuk memfasilitasi perubahan cara orangtua berkomunikasi; terhubung; dan mendukung remaja (Christian dkk., 2017).

Kondisi yang menyenangkan merupakan suatu cara yang sangat baik untuk menciptakan kebersamaan dan keakraban, dan salah satu keunggulan $A B C$ dibandingkan dengan pendekatan yang lain adalah banyak melakukan aktivitas yang menyenangkan. Seseorang yang menertawakan dirinya sendiri merupakan suatu cara yang sangat sehat ketika menghadapi situasi menegangkan (Herbert, 1996). Interaksi yang menyenangkan merupakan relaksasi untuk mempercepat terjadinya perubahan. $A B C$ bukan hanya memiliki manfaat psikologis tetapi juga fisik (Fletcher \& Hinkle, 2002). Tantangan fisik memungkinkan konseli untuk dapat mengekspresikan rasa frustasi dan kecemasan, sehingga dapat mengurangi stres. $A B C$ juga memiliki potensi yang tinggi untuk menstimulasi rasa keterlibatan dengan lingkungan sekitar sehingga meningkatkan kemampuan belajar seseorang. Pada konseling tradisional, konseli mungkin "menolak" atau menghindari konfrontasi-konfrontasi interpersonal, namun dalam $A B C$ aktivitas-aktivitas yang dilakukan dalam kelompok dapat memunculkan masalah dan agendaagenda tersembunyi. Pengalaman pada konseling tradisional lebih terbatas jika dibandingkan dengan pengalaman di luar ruangan sehingga dapat membantu proses perubahan pada individu (Fletcher \& Hinkle, 2002).

$A B C$ merupakan model konseling yang dapat disesuaikan melalui banyak pengaturan dan sengaja memanfaatkan kegiatan petualangan untuk memfasilitasi pertumbuhan sosio-emosional dan pribadi serta perilaku perubahan peserta (Fletcher \& Hinkle, 2002; Gass dkk., 2012). Selain itu, $A B C$ merupakan model kekuatan berbasis konseling (Glass \& Myers, 2001; Hill, 2007), dimana memungkinkan tindakan alami dari konselor/trainer untuk memfasilitasi wawasan pribadi dan menyediakan waktu di akhir setiap sesi kegiatan untuk memproses wawasan mereka. Tujuan penelitian ini adalah mengetahui keefektifan program $A B C$ untuk meningkatkan kebahagiaan mahasiswa.

\section{METODE}

Penelitian ini menggunakan pendekatan kuantitatif dengan rancangan penelitian pre-experimental design model one group pretest-posttest. Subjek adalah sebelas mahasiswa semester tiga program studi bimbingan dan konseling UAD yang dipilih dengan teknik purposive sampling. Pretest dilakukan menggunakan instrumen yang mengacu pada definisi kebahagiaan menurut Seligman. Definisi tersebut terdiri dari lima aspek, yaitu: emosi positif; keterlibatan; hubungan sosial positif; kebermaknaan hidup; dan prestasi. Subjek terpilih adalah mahasiswa yang hasil pretestnya menunjukkan bahwa mereka memiliki kebahagiaan yang rendah. Mahasiswa yang memiliki kebahagiaan rendah, dijadikan satu dalam kelompok eksperimen yang kemudian akan diberi perlakuan berupa $A B C$ selama tiga bulan. Tujuan intervensi program $A B C$ mengacu pada aspek kebahagiaan yang dikembangkan oleh Seligman, antara 
lain: meningkatkan perilaku sebagai wujud dari emosi positif mahasiswa; meningkatkan sikap memiliki keterikatan sosial untuk kesejahteraan diri sendiri dan orang lain di lingkungan kampus; meningkatkan sikap yang mampu membangun hubungan sosial positif di lingkungan kampus; mempertahankan sikap memiliki makna hidup yang mencakup prinsip serta makna dari tindakan yang dilakukan; dan meningkatkan kemampuan berprestasi sebagai mahasiswa. Tahapan program intervensi $A B C$ mengacu pada tahapan proses bimbingan dan konseling kelompok yaitu: tahap awal pembentukan kelompok (beginning a group/forming stage), tahap transisi (transition stage), tahap kerja (performing stage), dan tahap terminasi (termination stage).

Jumlah keseluruhan pertemuan $A B C$ sebanyak delapan kali pertemuan. Pertemuan pertama mengacu pada tahap pembentukan yang digunakan untuk membangun kontak serta hubungan antara konselor dengan konseli maupun konseli dengan konseli. Pertemuan kedua mempersiapkan konseli untuk masuk di tahap kerja atau inti pada setiap aspek kebahagiaan. Pertemuan ketiga sampai pertemuan ketujuh dikemas dengan permainan yang mengacu pada aspek kebahagiaan, pertemuan terakhir berisi refleksi dari setiap anggota selama proses $A B C$ dilaksanakan.

Perlakuan menggunakan $A B C$ dilakukan dalam suasana kelompok serta kegiatan-kegiatan/permainan kelompok untuk lebih merangsang kekritisan subjek dalam mentransformasi pengalaman sebagai proses meningkatkan atau pengembangan pengetahuan serta mengefektifkan keadaan suatu kelompok dalam menghadapi suatu masalah dalam hal ini adalah kebahagiaan. Pada tahap awal pembentukan kelompok, dipaparkan alasan kelompok tersebut dibentuk, untuk kepentingan apa, siapa anggota dan jumlahnya. Pada tahap awal juga dipaparkan mengenai kesepakatan kegiatan seperti peraturan kegiatan yang akan dilakukan dan batasan kegiatan (setting limit). Pada tahap awal, subjek melakukan berbagai penjajagan terhadap subjek lainnya mengenai hubungan antar pribadi yang dikehendaki kelompok, sekaligus mencoba berperilaku tertentu untuk mendapatkan reaksi dari anggota lainnya. Bersamaan dengan tampilnya perilaku individu yang berbeda, secara perlahan subjek mulai menciptakan pola hubungan antar sesama mereka. Pada tahap pertama secara berangsur-angsur mulai diletakkan pola dasar perilaku kelompok, baik yang berkaitan dengan tugas-tugas kelompok maupun yang berkaitan dengan hubungan pribadi antar anggota kelompok.

Tahap kedua dari proses pembentukan kelompok dimanfaatkan sebagai upaya memperjelas tujuan kelompok yang mulai menampakkan peningkatan partisipasi subjek. Sadar atau tidak sadar, pada tahap transisi, subjek mulai mendeteksi kekuatan dan kelemahan masing-masing anggota kelompok melalui proses interaksi yang intensif, ditandai dengan mulai terjadinya konflik antar subjek. Salah satu ciri dari fase transisi adalah dengan berbagai cara apapun, anggotanya akan saling memengaruhi satu sama lain.

Pada tahap kerja, kelompok sudah dibekali dengan suasana hubungan kerja yang harmonis antara anggota yang satu dengan yang lainnya. Norma kelompok telah disepakati; tujuan dan tugas kelompok serta peran masing-masing anggota kelompok telah jelas; kesadaran tanggung jawab masing-masing peserta telah dipahami; perbedaan pendapat ditolerir; inovasi berkembang (ibid); produktivitas kinerja meningkat; rasa keengganan dan keraguan anggota kelompok mulai terkikis (trust) di antara anggota kelompok. Iklim kelompok yang sesuai dengan perencanaan merupakan sinergi kelompok sehingga kelompok mampu menampilkan prestasi kerja yang optimal.

Tahap terminasi diarahkan untuk lebih mengenal diri sendiri, angggota kelompok yang lain, serta mengintegrasikan pengalaman-pengalaman yang didapatkan dari tahap awal (beginning stage) hingga tahap kerja (performing stage). Pada tahap terminasi diarahkan untuk merencanakan dan menindaklanjuti (follow up) pengalaman-pengalaman yang didapat dari rangkaian kegiatan yang telah dilewati. Pengalaman-pengalaman yang diperoleh ditransfromasikan dalam bentuk tindakan nyata yang diharapkan dan diaplikasikan dalam kehidupan nyata.

Setelah memberi perlakuan, peneliti melakukan analisis data dengan analisis statistik inferensial non-parametrik dengan teknik uji Wilcoxon untuk membandingkan rata-rata skor yang diperoleh sebelum dan sesudah diberi perlakuan. Kebahagiaan mahasiswa sebelum perlakuan diperoleh dari hasil pretest menggunakan angket kebahagiaan mahasiswa.

\section{HASIL}

Setelah serangkaian perlakuan selesai, posttest dilakukan untuk melihat keefektifan $A B C$. Setelah dilakukan posttest, diketahui bahwa terdapat perubahan skor aspek kebahagiaan subjek seperti yang disajikan pada gambar 1. Pada gambar 1, terlihat perubahan skor rata-rata yang bervariasi pada setiap 


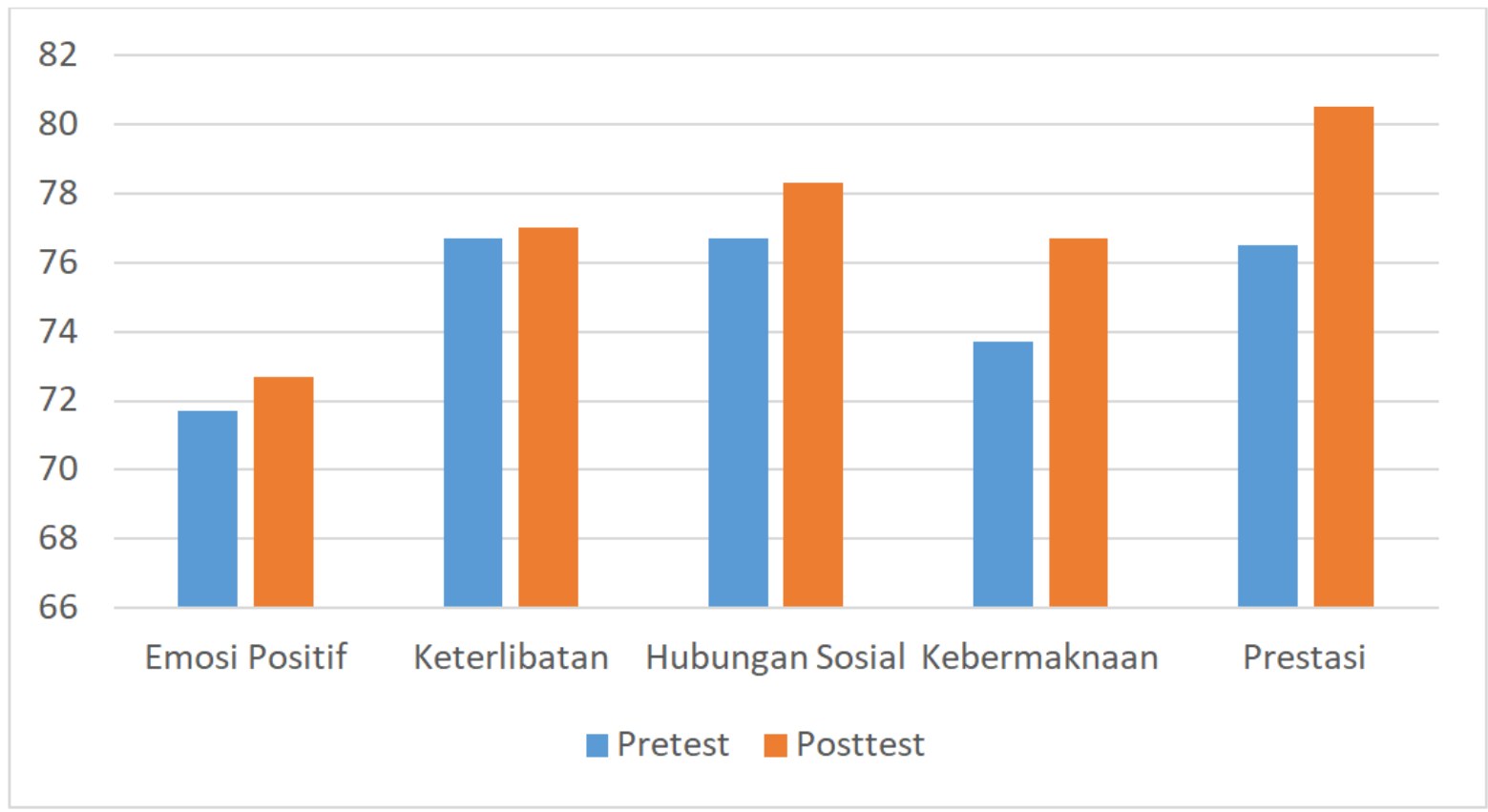

Gambar 1. Grafik Perubahan Skor Pretest - Posttest Kebahagiaan Mahasiswa

aspek. Hasil pretest menunjukkan aspek emosi positif yang berada pada kategori sedang dengan skor rata-rata 71,7 , berubah menjadi 72,7 . Aspek keterlibatan yang berada pada kategori sedang dengan skor 76,7, berubah menjadi 77. Aspek hubungan sosial positif berada pada kategori tinggi dengan skor 76,3, berubah menjadi 78,3. Aspek kebermaknaan yang berada pada kategori sedang dengan skor rata-rata 73,7 , berubah menjadi 76,7. Aspek prestasi yang berada pada kategori tinggi dengan skor rata-rata 76,5, berubah menjadi 80,5 .

Analisis data dengan analisis statistik inferensial non-parametrik dengan teknik uji Wilcoxon menunjukkan bahwa nilai signifikan adalah 0,798 , yang artinya $>0,05$. Hal ini berarti secara umum pemberian program $A B C$ tidak berpengaruh signifikan terhadap kebahagiaan mahasiswa. Namun, terdapat pengaruh program $A B C$ yang cukup signifikan pada aspek kebermaknaan dan prestasi. Hasil uji statistik aspek kebermaknaan menunjukkan nilai signifikan 0,150 , yang artinya $<0,05$. Maka pemberian program $A B C$ berpengaruh signifikan terhadap kebahagiaan mahasiswa pada aspek hubungan kebermaknaan. Hasil uji statistik aspek prestasi menyatakan bahwa nilai signifikan 0,388 yang artinya $<0,05$. Maka pemberian program $A B C$ berpengaruh signifikan terhadap kebahagiaan mahasiswa pada aspek prestasi.

\section{PEMBAHASAN}

Kebahagiaan (subjective well being) didefinisikan sebagai keadaan psikologis positif yang ditandai dengan tingginya derajat kepuasan hidup; afek positif; dan rendahnya derajat afek negatif (Carr, 2013). Kebahagiaan merupakan sebuah konstruk kompleks yang disusun atas konstruk-konstruk sederhana di dalamnya. Berbagai istilah digunakan untuk mendeskripsikan keadaan positif yang berkaitan dengan kebahagiaan. Istilah pertama adalah kesejahteraan subjektif (subjective well being), yaitu persepsi individu tentang seberapa puas hidupnya, sebagai evaluasi berkelanjutan terhadap peristiwa kehidupan. Kebahagiaan (well-being) meliputi lima komponen pembentuk yaitu: emosi positif(Positive Emotion/P); keterlibatan (Engagement/E); hubungan sosial positif (Positive Relationship/R); kebermaknaan hidup (Meaning/M) dan prestasi (Accomplishment/A)(Seligman, 2012).

Sebuah hal dasar untuk dapat memiliki kebahagiaan adalah dengan mengembangkan suatu hubungan atau interaksi yang hangat dan mendalam dengan orang lain (Andersen \& Guerrero, 1997). Pernyataan lain menyebutkan seseorang akan merasakan kebahagiaan saat dirinya telah memiliki segala hal baik seperti: (1) kesehatan dan kemakmuran; (2) persahabatan; (3) pengetahuan; dan (4) kebajikan (Carr, 2013). Menurut beberapa hasil penelitian, $A B C$ dapat digunakan untuk meningkatkan kebahagiaan (Albright, 2016; Nugraha, 2018). 
$A B C$ yang berakar dari tradisi filsafat "experiential" yang diartikan sebagai "learning by doing, with reflection" (Glass \& Benshoff, 2002). Belajar dengan "experiential" didasarkan pada keyakinan bahwa belajar merupakan hasil pengalaman individu secara langsung, dan belajar yang terbaik terjadi jika melibatkan semua perasaan individu (multiple sense) secara aktif. $A B C$ merupakan model konseling yang dapat disesuaikan melalui banyak pengaturan dan sengaja memanfaatkan kegiatan petualangan untuk memfasilitasi pertumbuhan sosio-emosional dan pribadi serta perilaku perubahan peserta (Fletcher \& Hinkle, 2002; Gass dkk., 2012). Selain itu, $A B C$ merupakan model kekuatan berbasis konseling (Glass \& Myers, 2001; Hill, 2007), dimana memungkinkan terjadinya tindakan alami konselor untuk memfasilitasi wawasan pribadi dan menyediakan waktu di akhir setiap sesi kegiatan untuk memproses wawasan konseli.

Kohesi kelompok merupakan variabel penting untuk proses kelompok (Stockton dkk., 1992). Kohesi di dalam kelas dapat terbentuk ketika kelompok diminta untuk bekerjasama dalam berbagai tugas, dan $A B C$ merupakan salah satu metode yang dapat digunakan. $A B C$ menggunakan pendidikan experiential dalam latar outdoor dengan tujuan meningkatkan: harga diri; kepercayaan terhadap orang lain; dan perilaku positif mahasiswa (Glass \& Myers, 2001). Tujuh elemen kunci $A B C$ adalah: membangun kepercayaan (trust building); tujuan yang ingin dicapai (goal setting); tantangan (challenge); peak experiences; kegembiraan (humor/fun); dan penyelesaian masalah (problem solving) (Schoel dkk., 1988).

Peran konselor dalam $A B C$ adalah menyusun elemen untuk setiap partisipan dalam bentuk skenario dan menjelaskan tugas masing-masing kelompok. $A B C$ memberikan kesempatan kepada seluruh anggota kelompok untuk mendiskusikan pengalamannya secara detail, menghubungkannya dengan kehidupan sehari-hari dan menemukan makna kegiatan (Glass \& Myers, 2001). Dalam $A B C$, teknik untuk menilai proses kelompok adalah: processing; activity; relationships; and self (PARS). Model PARS membantu anggota untuk mengidentifikasi dan menguji apa yang terjadi dalam kelompok dan bagaimana reaksi anggota terhadap pengalaman kelompok. Proses model PARS melibatkan tahap reflecting, understanding, dan applying (Glass \& Myers, 2001).

Hasil penelitian menunjukkan terdapat dua aspek kebahagiaan yang meningkat setelah mengikuti program $A B C$. Kedua aspek tersebut adalah kebermaknaan dan prestasi. Peningkatan tersebut dapat dilihat dari pola kelompok yang menunjukkan anggota kelompok cukup memerhatikan prestasi sebagai salah satu indikator dari kebahagiaan. Berdasarkan hasil dari pencermatan diskusi yang berlangsung, nampak anggota kelompok merasa diri mereka bermakna dan mampu mencapai kebahagiaan ketika mampu menunjukkan prestasi yang baik. Sedangkan pada aspek emosi positif; keterlibatan; dan hubungan sosial tidak terjadi peningkatan signifikan yang dapat disebabkan oleh beberapa faktor. Ketiga aspek tersebut berkaitan dengan lingkungan sosial dimana pada kasus kelompok ini tidak menjadi tolok ukur utama untuk mencapai kebahagiaan. Dalam pencapaian kebahagiaan pada usia dibawah 30 tahun, pendidikan memang menjadi faktor setingkat lebih tinggi dibanding lingkungan sosial (Dunn dkk., 2011).

\section{SIMPULAN}

Berdasarkan hasil uji statistik, program $A B C$ belum efektif untuk meningkatkan kebahagiaan mahasiswa secara menyeluruh. Kendati demikian, secara practical significant, program ABC melahirkan perubahan kebahagiaan pada mahasiswa yang terlihat dari peningkatan skor posttest pada aspek-aspek tertentu. Perubahan kualitatif yang paling dominan tampak pada aspek kebermaknaan dan prestasi dimana mahasiswa lebih mempunyai pandangan tujuan hidup setelah lulus kuliah; datang kuliah tepat waktu; berusaha untuk mengurangi kebiasaan buruk dalam belajar; dan menyadari keterampilan baru yang diperoleh saat kuliah akan membantu dalam mendukung masa depan.

\section{DAFTAR RUJUKAN}

Albright, R. L. (2016). The Qualitative Impact of Adventure Based Counseling on Sixth Grade General Education Students. Journal of School Counseling, 14(8), n8.

Andersen, P. A., \& Guerrero, L. K. (1997). Handbook of Communication and Emotion: Research, Theory, Applications, and Contexts. Elsevier. 
Carr, A. (2013). Positive Psychology: The Science of Happiness and Human Strengths. Routledge.

Christian, D. D., Perryman, K. L., \& Portrie-Bethke, T. L. (2017). Improving the Parent-Adolescent Relationship With Adventure-Based Counseling: An Adlerian Perspective. Journal of Child and Adolescent Counseling, 3(1), 44-58. https://doi.org/10.1080/23727810.2017.1281693

DeDiego, A. C., Wheat, L. S., \& Fletcher, T. B. (2017). Overcoming Obstacles: Exploring the Use of Adventure Based Counseling in Youth Grief Camps. Journal of Creativity in Mental Health, 12(2), 230-241. https://doi. org/10.1080/15401383.2016.1191403

Dunn, D. S., Beard, B. M., \& Fisher, D. J. (2011). On Happiness: Introducing Students to Positive Psychology. Promoting Student Engagement, 2, 207-216.

Fleischer, C., Doebler, P., Bürkner, P.-C., \& Holling, H. (2017). Adventure Therapy Effects on Self-Concept-A Meta-Analysis.

Fletcher, T. B., \& Hinkle, J. S. (2002). Adventure Based Counseling: An Innovation in Counseling. Journal of Counseling \& Development, 80(3), 277-285.

Gass, M. A., Gillis, H. L., \& Russell, K. C. (2012). Adventure Therapy: Theory, Practice, \& Research.

Glass, J. S., \& Benshoff, J. M. (2002). Facilitating Group Cohesion Among AdolescentsThrough Challenge Course Experiences. Journal of Experiential Education, 25, 268-278.

Glass, J. S., \& Myers, J. E. (2001). Combining the Old and The New to Help Adolescents: Individual Psychology and Adventure-Based Counseling. Journal of Mental Health Counseling, 23(2), 104-114.

Hapsari, D. F. (2015). Hubungan antara Religiusitas dan Kebahagiaan pada Siswa. Universitas Muhammadiyah Surakarta.

Herbert, J. T. (1996). Use of Adventure-Based Counseling Programs for Persons with Disabilities. Journal of Rehabilitation, 62(4), 3.

Hill, N. (2007). Wilderness Therapy as A Treatment Modality For At-Risk Youth: A Primer for Mental Health Counselors. Journal of Mental Health Counseling, 29(4), 338-349.

Kusherdyana, Ahman, Nurihsan, A. J., \& Rusmana, N. (2016). Model Konseling Berbasis Petualangan untuk Meningkatkan Kecerdasan Adversitas Mahasiswa. Edusentris, 3(3), 256-268. https://doi.org/10.17509/ edusentris.v3i3.236

Moseley, C. (2010). Atlas of the World's Languages in Danger. UNESCO.

Nugraha, A. (2018). Adventure Based Counseling dalam Layanan Bimbingan dan Konseling Kelompok. Journal of Innovative Counseling: Theory, Practice, and Research, 2(02), 75-83.

Schoel, J., Prouty, D., \& Radcliffe, P. (1988). Islands of Healing. A Guide to Adventure Based Counseling. MA: Project Adventure.

Seligman, M. E. P. (2012). Flourish: A Visionary New Understanding of Happiness and Well-Being. Simon and Schuster.

Siahaan, C. (2014). Setengah Dari Jumlah Gadis Muda Kota Hilang Keperawanan. Diambil 12 Februari, 2016, dari http://beritakaltara.com/setengah-dari-jumlah-gadis-muda-kota-hilang-keperawanan/

Somarya, R., \& Nuryani, P. (2011). Landasan Pendidikan. Bandung: Sub Koordinator MKDP Landasan Pendidikan $U P I$. Universitas Pendidikan Indonesia.

Stockton, R., Rohde, R. I., \& Haughey, J.(1992). TheEffects of Structured GroupExercises on Cohesion, Engagement, Avoidance, and Conflict. Small Group Research, 23(2), 155-168. https://doi.org/10.1177/1046496492232001

Tucker, A. R. (2009). Adventure-Based Group Therapy to Promote Social Skills in Adolescents. Social Work With Groups, 32(4), 315-329. https://doi.org/10.1080/01609510902874594

Tucker, A. R., Javorski, S., Tracy, J., \& Beale, B. (2013). The Use of Adventure Therapy in Community-Based Mental Health: Decreases in Problem Severity Among Youth Clients. Child \& Youth Care Forum, 42(2), 155-179. https://doi.org/10.1007/s10566-012-9190-x

Whittington, A., Aspelmeier, J. E., \& Budbill, N. W. (2016). Promoting Resiliency in Adolescent Girls through Adventure Programming. Journal of Adventure Education and Outdoor Learning, 16(1), 2-15. https://doi.or $\mathrm{g} / 10.1080 / 14729679.2015 .1047872$ 